\title{
Study on Temperament of Scholastically Backward Children
}

\author{
Dr. Jitendra Mugali ${ }^{1}$, Dr. Nitin Pattanashetty ${ }^{2}$, Dr. S S Chate ${ }^{3}$, Dr. N M Patil ${ }^{4}$, \\ Dr. Sandeep Patil ${ }^{5}$, Dr. Bheemsain Tekkalaki ${ }^{6}$, Dr Mallikarjun A Pattanashetti ${ }^{7}$
}

\section{ABSTRACT}

Objectives: 1.To studies the categorical prevalence of temperament of scholastically backward children. 2. To study the associated Psychiatric problems with type of temperament in scholastically backward children. Material and Methods: Total of 1480 children studying in 3 CBSE schools, aged between 6 and 12 years were screened. 312 children were found to scholastically backward. After simple randomization and further screening procedure 115 children were included in the study. Each child was assessed by interviewing with MINI-KID Questionnaire, temperament assessment scale, I Q assessment by using Reven's coloured progressive matrices, CBCL and final diagnosis done by ICD DCR criteria. Statistical analysis was done using Epi Info 7 software. Results: The prevalence of scholastically backwardness was found to be $21.08 \%$. The distribution of scholastically backward children belongs to falling types of temperament found to be easy temperament- $41.74 \%$, difficult temperament $13.91 \%$ and slow to warm temperament $44.35 \%$ respectively. Majority of scholastically backward children belongs to slow to warm type of temperament. All the difficult temperament children were associated with one or the other psychiatric problems. $18.75 \%$ of children with easy temperament and $74.51 \%$ of children with slow to warm are associated with psychiatric problems. Conclusion: Temperament of a child is one of the major factors for scholastic performance. Some children do poor performance in academics, school refusal and school drop outs. Prevalence of difficult temperament in children had associated with $100 \%$ psychiatric disorder. Difficult temperament

\footnotetext{
${ }^{1}$ Assistant Professor, Department of Psychiatry, Gadag Institute of Medical Sciences, Gadag. Karnataka state, India

${ }^{2}$ Assistant Professor, Department of Psychiatry, USM-KLE International Medical Programme, Belagavi. Karnataka state, India

${ }^{3}$ Associate Professor Department of Psychiatry, J N Medical College, Belagavi. Karnataka state, India

${ }^{4}$ Professor and head Department of Psychiatry, J N Medical college, Belagavi. Karnataka state, India

${ }^{5}$ Assistant Professor Department of Psychiatry, J N Medical college, Belagavi. Karnataka state, India

${ }^{6}$ Assistant Professor Department of Psychiatry, J N Medical college, Belagavi. Karnataka state, India

${ }^{7}$ Assistant Professor Department of Pathology, S N Medical College, Bagalkot. Karnataka state, Country, India

*Responding Author
}

Received: December 25, 2016; Revision Received: February 4, 2017; Accepted: February 7, 2017

(C) 2017 Mugali J, Pattanashetty N, Chate S, Patil N, Patil S, Tekkalaki B, Mallikarjun Pattanashetti; licensee IJIP. This is an Open Access Research distributed under the terms of the Creative Commons Attribution License (www.creativecommons.org/licenses/by/2.0), which permits unrestricted use, distribution, and reproduction in any Medium, provided the original work is properly cited. 


\section{Study on Temperament of Scholastically Backward Children}

children handling in home and in school is very difficult, so early detection of associated psychiatric problems and early intervention will surely help to handle the further consequences.

Keywords: Temperament, Scholastic backwardness, children

Current trends in education or academic performance and social development of child correspond to the temperament of the child. Every child falls into either one type of the temperament group following the infancy stage gets over and starts with early childhood life. Definition of Child temperament given by Rothbart \& Bates defined as 'constitutionally based individual differences in emotional, motor, and attention reactivity and self-regulation is modestly related to concurrent and later child adjustment. For example, while very poor attention may manifest as attention deficit disorder, excessive fearfulness may manifest as anxiety disorder, Studies done by Chess and Thomas had defined clusters of temperament characteristics they hypothesized were most clinically salient for adjustment. The review article by K.C. Gallagher had explained that moderate to high positive emotion, moderate activity level, high adaptability and high emotional regulation as exhibited by children with an "easy", temperament. Children with 'difficult”' temperament typically exhibited high negative emotion, low adaptability, high activity level, and low emotional regulation. Children with the difficult characteristics were found to challenge parents, caregivers, and teachers, more than children with "'easy" or average temperament. Temperament consists of relatively consistent, basic dispositions inherent in the person that underlie and modulate the expression of activity, reactivity, emotionality, and sociability.

The behavior of children sets over a time, depend up on temperament of child and also goes on change in behavior as the child grows depends on temperament. Although little was known then about the long-term outcomes of temperament traits, there Child Development Perspectives, are now well-documented connections between temperament and a wide variety of critical life outcomes-relationships, academic achievement, health, and psychopathology. A common metaphor for thinking about personality development has been that young children display genetically influenced temperament traits and that in later life displays as personality traits of an adult. An Child Development Perspectives, 5 alternative possibility is that temperament traits in childhood and the Big Five traits in adulthood may be manifestations of the same basic dimensions. From this point of view, personality traits are broader in content because biological maturation and expanding experiences permit the expression of new facets of the underlying traits. If this second possibility is correct, temperament research could be enhanced by measuring traits more broadly as children get older.

Also associated psychiatric problems with personality traits can be guessed. Most of the time the types of temperament of child leads to a factor in achievement in academics. Otherwise the around scholastically backwardness leading to change in temperament, i.e. surrounding 


\section{Study on Temperament of Scholastically Backward Children}

environment and social reorganization in school/class plays a important role. In turn affects the Childs psychological conditions.

So this article mainly focuses on how the temperament of child influences the low performance in his/her education and reveals the association of temperament of child with psychiatric disorder among children with scholastical backwardness.

\section{METHODS AND MATERIALS}

Children studying in CBSE school, age group of 6 to 12 years scoring $\mathrm{C}$ grade and below were identified with the help of children school progress cards. As per simple randomization procedure done on students with $\mathrm{C}$ grade and below, every alternate child starting from first student in the list was recruited into the study. Detailed history was obtained from parents and teachers. Each recruited child was subjected for visual and hearing tests to rule out visual and hearing impairments. Then these children were subjected to physical examination to rule out major medical problems. These children were also subjected to I.Q testing to rule out intellectual disability by using Reven's Coloured Progressive Matrices. Following screening, each child subjected to MINI-KID Questionnaire and Childhood Behaviora Check List (CBCL), by using CBCL somatic complaints were assessed. NIMHANS Index for Specific Learning Disorders. Temperament of children was assessed by Temperament Assessment Scale. The final diagnosis was made using ICD 10 DCR criteria statically analysis done using WHO Epi Info 7 software.

\section{RESULTS}

Total of 1480 children studying in 3 CBSE schools, aged between 6 and 12 years were screened. 312 children were found to scholastically backward. After simple randomization and further screening procedure 115 children were included in the study and successfully completed the study.

Table no 1 shows that distribution of children according to the type of temperament they belongs. $41.74 \%, 13.91 \%$ and $44.35 \%$ ere belongs to easy temperament, difficult temperament and slow to warm temperament respectively.

Table no 1: Prevalence of type of temperament in children with scholastically backwardness. $N=115$

\begin{tabular}{|c|l|l|}
\hline Temperament of child & No of children (N) & Percentages \\
\hline 1. Easy & 48 & $41.74 \%$ \\
\hline 2. Difficult & 16 & $13.91 \%$ \\
\hline 3. Slow to warm & 51 & $44.35 \%$ \\
\hline Total & $\mathbf{1 1 5}$ & $\mathbf{1 0 0 \%}$ \\
\hline
\end{tabular}

Table no 2 shows that gender wise distribution of children according to the type of temperament they belongs. $42.67 \%, 18.67 \%$ and $38.67 \%$ of boys belongs to easy, difficult and slow to warm

(C) The International Journal of Indian Psychology, ISSN 2348-5396 (e)| ISSN: 2349-3429 (p) | 167 


\section{Study on Temperament of Scholastically Backward Children}

temperament respectively. $40.0 \%, 5.0 \%$ and $55.0 \%$ of girls belongs to easy, difficult and slow to warm temperament respectively.

Table no 2: Gender wise distribution of temperament in scholastically backwardness children. $N=115$

\begin{tabular}{|c|c|c|c|c|c|c|}
\hline \multirow{2}{*}{\multicolumn{2}{|c|}{ Variables }} & \multicolumn{2}{|l|}{ Gender } & \multirow{2}{*}{$\begin{array}{l}\text { Total no of } \\
\text { children/\% }\end{array}$} & \multirow{2}{*}{$\begin{array}{l}\text { Chair- } \\
\text { square }\end{array}$} & \multirow[t]{2}{*}{ P-value } \\
\hline & & Boys (N/\%) & Girls (N/\%) & & & \\
\hline \multirow{3}{*}{$\begin{array}{l}\text { Temperament } \\
\text { of children }\end{array}$} & Easy & 32 (42.67\%) & $16(40.00 \%)$ & 48 (41.74\%) & \multirow[t]{4}{*}{5.11} & \multirow[t]{4}{*}{$0.07 *$} \\
\hline & Difficult & 14(18.67\%) & $02(5.00 \%)$ & 16(13.91\%) & & \\
\hline & $\begin{array}{l}\text { Slow to } \\
\text { warm }\end{array}$ & $29(38.67 \%)$ & $22(55.00 \%)$ & $51(44.35 \%)$ & & \\
\hline \multicolumn{2}{|l|}{ Total } & $75(100.0 \%)$ & $40(100.0 \%)$ & $115(100.0 \%)$ & & \\
\hline
\end{tabular}

$* \mathrm{p}<0.05$

Table no 3: Presence of psychiatric problems in participants with their temperament. $N=115$

\begin{tabular}{|l|c|c|c|c|c|l|l|}
\hline \multicolumn{2}{|c|}{ Variable } & \multicolumn{3}{c|}{ Temperament of child } & $\begin{array}{c}\text { Total no } \\
\text { of } \\
\text { children } \\
\text { N / (\%) }\end{array}$ & $\chi^{2}$ & P \\
\cline { 2 - 7 } & $\begin{array}{c}\text { Easy } \\
\text { N (\%) }\end{array}$ & $\begin{array}{c}\text { Difficult } \\
\text { N / (\%) }\end{array}$ & $\begin{array}{l}\text { Slow to warm } \\
\text { N / (\%) }\end{array}$ & $\begin{array}{c}63 \\
(54.78 \%)\end{array}$ & 46.37 & $0.00 *$ \\
\hline $\begin{array}{l}\text { Psychiatric } \\
\text { problems } \\
\text { among } \\
\text { children with } \\
\text { scholastically } \\
\text { backward. }\end{array}$ & Present & $9(18.75 \%)$ & $16(100 \%)$ & $38(74.51 \%)$ & $\begin{array}{c}52 \\
(45.22 \%)\end{array}$ & & \\
\cline { 2 - 6 } & Absent & $39(81.25 \%)$ & 0 & $13(25.49 \%)$ & $\begin{array}{c}115 \\
(100 \%)\end{array}$ & & \\
\hline \multicolumn{2}{|l|}{\begin{tabular}{l} 
Total \\
\hline
\end{tabular}} & $48(100 \%)$ & $16(100 \%)$ & $51(100 \%)$ & & \\
\hline
\end{tabular}

$* \mathrm{p}<0.05$

Table no 3 shows that presence of psychiatric problems in participants with their temperament. $18.75 \%, 100 \%$ and $74.51 \%$ of the easy, difficult and slow to warm temperament in participant were having psychiatric problems. $\mathrm{P}$ value is 0.00 which is significant $\mathrm{p}<0.05$

Table no 4 shows that associated psychiatric problems with temperament of scholastically backward children. 20\%, 50\% and $30 \%$ of easy temperament children were associated with emotional disorders (anxiety disorders), specific learning disorders (SpLD) and sleep disorder respectively. 5\% (Emotional disorders), 5\% (Borderline intellectual disability), 5\% (Specific learning disorder), 35\% (Conduct disorder), 35\% (Hyperkinetic disorder) and 10\% (substance abuse) of scholastically backward children were belonging to difficult temperament. $45.10 \%$ (Emotional disorders), 27.45\% (Borderline intellectual disability), 11.76\% (Specific learning disorder), 1.96\% (sleep disorder) and 5.88\% (mood disorder) of scholastically backward children were belonging to slow to warm temperament.

(C) The International Journal of Indian Psychology, ISSN 2348-5396 (e) | ISSN: 2349-3429 (p) | 168 
Table no 4: Association of temperament and Psychiatric problems among scholastically backward children ( $N$ 115)

\begin{tabular}{|c|c|c|c|c|c|c|}
\hline \multicolumn{2}{|c|}{ Variable } & \multicolumn{3}{|c|}{ Temperament of child } & \multirow{3}{*}{$\begin{array}{l}\text { Chi- } \\
\text { Square }\end{array}$} & \multirow[t]{3}{*}{ P value } \\
\hline & & $\begin{array}{c}\text { Easy } \\
\text { N / ( \%) }\end{array}$ & $\begin{array}{l}\text { Difficult } \\
\text { N / (\%) }\end{array}$ & $\begin{array}{c}\text { Slow to } \\
\text { Warm } \\
\text { N / ( \%) }\end{array}$ & & \\
\hline \multirow{9}{*}{$\begin{array}{l}\text { Psychiatric } \\
\text { problems in } \\
\text { scholastically } \\
\text { backward } \\
\text { children }\end{array}$} & Emotional & 2 & & 23 & & \\
\hline & disorders & $(20.0 \%)$ & $(5.00 \%)$ & $(45.10 \%)$ & 26.51 & $0.000 *$ \\
\hline & $\begin{array}{c}\text { Borderline } \\
\text { intellectual } \\
\text { disability }\end{array}$ & 0 & $\begin{array}{c}1 \\
(5.00 \%)\end{array}$ & $\begin{array}{c}14 \\
(27.45 \%)\end{array}$ & 17.18 & $0.0002 *$ \\
\hline & $\begin{array}{l}\text { Specific } \\
\text { learning } \\
\text { disorder } \\
\end{array}$ & $\begin{array}{c}5 \\
(50.00 \%)\end{array}$ & $\begin{array}{c}1 \\
(5.00 \%)\end{array}$ & $\begin{array}{c}6 \\
(11.76 \%)\end{array}$ & 0.3963 & 0.8202 \\
\hline & $\begin{array}{l}\text { Conduct } \\
\text { disorder }\end{array}$ & 0 & $7(35.0 \%)$ & 0 & 46.11 & $0.00^{*}$ \\
\hline & $\begin{array}{c}\text { Hyperkinetic } \\
\text { disorder }\end{array}$ & 0 & 7 (35.0\%) & 0 & 46.11 & $0.00 *$ \\
\hline & Sleep disorder & $\begin{array}{c}3 \\
(30.00 \%) \\
\end{array}$ & $\begin{array}{c}1 \\
(5.00 \%)\end{array}$ & $\begin{array}{c}1 \\
(1.96 \%) \\
\end{array}$ & 1.25 & 0.53 \\
\hline & Mood disorder & 0 & 0 & $\begin{array}{c}3 \\
(5.88 \%) \\
\end{array}$ & 3.86 & 0.144 \\
\hline & $\begin{array}{c}\text { Substance } \\
\text { abuse }\end{array}$ & 0 & $\begin{array}{c}2 \\
(10.0 \%)\end{array}$ & 0 & 12.59 & $0.001^{*}$ \\
\hline
\end{tabular}

$* \mathrm{p}<0.05$

\section{DISCUSSION}

With reference to the above mentioned results, the prevalence of types of temperament among children with scholastically backward showed $44.35 \%$ of the study participants belong to slow to warm type of temperament. All the participants with difficult temperament were had psychiatry problem.

The significance of temperament lies, in part, in the assumption that early temperament shapes behaviour and personality development. Influences social developmental outcomes. Child temperament has been seen as a possible precursor to behavioral problems. The difficult temperament children were associated with substance abuse, ADHD and conduct disorder. So these difficult temperament children has behavioral manifestation leads in poor performance in academics and difficult manage at home and school. Also, the link between temperament in early childhood and later behavioral problems has been well documented. For example, dimensions associated with difficult temperament (e.g., emotionality, adaptability, approach/withdrawal, impulsivity) are predictive of both internalizing and externalizing problems, externalizing

(c) The International Journal of Indian Psychology, ISSN 2348-5396 (e)| ISSN: 2349-3429 (p) | 169 


\section{Study on Temperament of Scholastically Backward Children}

problems were predicted by activity level, and shyness and fearfulness predicts the internalizing problems. Importantly, these associations do not appear to be an artifact due to similarity of items on measures used to assess both temperament and problem behavior. $45.10 \%$ of the slow to warm study participants were associated with emotional disorders (anxiety spectrum disorder). Slow to warm children had exam anxiety and separation anxiety disorder in turn may lead to low performance in academics.

There were no significant shared environmental influences on any of the observed associations. Likewise, a study of fear and anxiety symptoms in early childhood found that in adult suffering from anxious avoidant personality disorder, GAD (generalized anxiety disorder] and phobic anxiety disorders. Our study result are on far with other studies. Also most of our study p values are statistical significant. There are very few studies in India and our study is the only one which shows the type of temperament associated with psychiatric problems among children with scholastical backwardness.

\section{CONCLUSION}

Temperament of a child is one of the major factors for scholastic performance. Some children do poor performance in academics, school refusal and school drop outs. Prevalence of difficult temperament in children had associated with $100 \%$ psychiatric disorder. Difficult temperament children handling in home and in school is very difficult, so early detection of associated psychiatric problems and early intervention will surely help to handle the further consequences. We hope that this basic research increasingly will be applied to improve the quality of children's lives.

\section{Acknowledgments}

The author appreciates all those who participated in the study and helped to facilitate the research process.

Conflict of Interests: The author declared no conflict of interests.

\section{REFERENCES}

Campbell SB. Behavior problems in preschool children: A review of recent research. J Child Psychol 1995;36:113-149.

Chess, S., \& Thomas, A. Issues in the clinical application of temperament. In G. A.Kohnstamm, J. E. Bates, \& M. K. Rothbart (Eds.), Temperament in childhood . 1989; 377- 403.

Clark, L. A., \& Watson, D. Temperament: An organizing paradigm for trait psychology. In O. P. John, R. W. Robins, \& L. A. Pervin (Eds.), Handbook of personality: 2008; Theory and research 265-286.

Fagan J. The interaction between child sex and temperament in predicting behavior problems of preschool-age children in day care. Early Child Dev and Care 1990;59:1-9. 


\section{Study on Temperament of Scholastically Backward Children}

Fagot BI, O’ Brien M. Activity level in young children: Cross-age stability, situational influences, correlates with temperament, and the perception of problem behaviors. Merrill Palmer Quarterly 1994;40:378-398.

Goldsmith HH, Lemery KS. Linking temperamental fearfulness and anxiety symptoms: A behavioralgenetic perspective. Biol Psychiatry 2000;48:1199-1209.

Guerin DW, Gottfried AW, Thomas CW. Difficult temperament and behavior problems: A longitudinal study from 1.5 to 12 years. Int J Behav Dev 1997;21:71-90.

Lavigne JV, Gibbons RD, Christoffel KK, et al. Prevalence rates and correlates of psychiatric disorders among preschool children. J Am Acad Child Adoles Psychiatry 1996;35:204214.

Lemery KS, Essex MJ, Smider NA. Revealing the relation between temperament and behavior problem symptoms by eliminating measurement confounding: Expert ratings and factor analyses. Child Dev 2002;73:867-882.

Lengua LJ, West SG, Sandler IN. Temperament as a predictor of symptomatology in children: Addressing contamination of measures. Child Dev 1988;69:164-181.

McCrae, R. R., Costa, P. T., Jr., Ostendorf, F., Angleitner, A., Hrebickova, M., Avia, M. D., et al. Nature over nurture: Temperament, personality, and life span development. Journal of Personality and Social Psychology, 2000; 78, 173-186.

Mehregany DV. The relation of temperament and behavior disorders in a preschool clinical sample. Child Psychiatry Hum Dev 1991;22:129-136. [PubMed: 1800024]

Roberts, B. W., \& DelVecchio, W. F. The rank-order consistency of personality traits from childhood to old age: A quantitative review of longitudinal studies. Psychological Bulletin, 2000; 126, 25-30.

Rothbart, M. K. (2011). Becoming who we are: Temperament and personality in development. New York: Guilford.

Rothbart, M. K. Temperament and development. In G. A. Kohnstamm, J. E. Bates, \& M. K. Rothbart (Eds.), Temperament in childhood.1999; 247-287.

Rothbart, M. K., \& Bates, J. E. Temperament. In N. Eisenberg (Ed.), Social, emotional and personality development. 1998; Vol. 3, 5th ed,105-176.

Rubin KH, Burgess KB, Dwyer KM, et al. Predicting preschoolers' externalizing behaviors from toddler temperament, conflict, and maternal negativity. Dev Psychol 2003;39:164-176.

Rutter M. Temperament, personality, and personality disorder. Br J Psychiatry 1987;150:443458.

Schmitz S, Fulker DW, Plomin R, et al. Temperament and problem behavior during early childhood. Int J Behav Dev 1999;23:333-355.

Shiner, R. L., \& Caspi, A. Temperament and the development of personality traits, adaptations, and narratives. In M. Zentner \& R. L. Shiner (Eds.), Handbook of temperamen. 2012; 497-516. 


\section{Study on Temperament of Scholastically Backward Children}

Shiner, R. L., \& Caspi, A. Temperament and the development of personality traits, adaptations, and narratives. In M. Zentner \& R. L. Shiner (Eds.), Handbook of temperament 2012; 497-516.

Teglasi H, MacMahon BH. Temperament and common problem behaviors of children. $J$ Appl Dev Psychol 1990;11:331-349.

Thomas, A. Temperament research: Where we are, where we are going. Merrill-Palmer Quarterly, 84;30(2), 103-109.

How to cite this article: Mugali J, Pattanashetty N, Chate S, Patil N, Patil S, Tekkalaki B, M Pattanashetti (2017), Study on Temperament of Scholastically Backward Children, International

Journal of Indian Psychology, Volume 4, Issue 2, No. 88, ISSN:2348-5396 (e), ISSN:2349-3429 (p), DIP:18.01.077/20170402, ISBN:978-1-365-74161-6 